\title{
Smoking Behavior on Health Workers in Indonesia: A Phenomenological Study
}

\author{
Titih Huriah ${ }^{1, *}$ Arif Rahman ${ }^{2}$
}

\author{
${ }^{1}$ Master of Nursing, Postgraduate Program, Universitas Muhammadiyah Yogyakarta, Kampus Terpadu UMY, Jl. \\ Brawijaya, Kasihan,Bantul, Yogyakarta, Indonesia \\ ${ }^{2}$ Stikes Yahya Bima, Jln Lintas Talabiu, Woha, Bima Nusa Tenggara Barat Indonesia, 84171. \\ *Corresponding author.Email: titih.huriah@umy.ac.id
}

\begin{abstract}
Smoking behavior is a global health threat. Indonesia ranks third after China and India, with the most significant number of smoking behaviors in the world. Indonesia has implemented a No Smoking Area policy in the workplace and health facilities, but its implementation in the field is still not consistently implemented. The average smoking behavior of health workers in Indonesia was 20\%. The research was to explore the smoking behavior on health workers at Nusa Tenggara Barat Province, Indonesia. The research design used a phenomenology study toward 6 participants based on snowball sampling technique. The research generated six themes: 1) The early experience of smoking behavior since middle school, 2) The reasons of smoking behavior were psychological and environment factors, 3) The effects of smoking behavior were physiological, psychological, economy, interpersonal and situational effect, 4) The commitment to quit smoking: having desires quit smoking but has not succeeded, 5) The problematic smoking behavior to change: smoking becomes a daily routine, 6) The obstacles to educating people on smoking behavior: not daring to provide health education on smoking behavior. The health workers who smoke have constraints to educate people in the working environment about smoking behavior.
\end{abstract}

Keywords: health promotion, health workers, smoking behavior, Indonesia, Phenomenological study

\section{INTRODUCTION}

Health workers become role models in the prevention of smoking behavior, play an active role in educating the effects of the dangers of smoking as well as providing stop smoking therapy, and providing support for quitting smoking. Pender [1996], in the Health Promotion Model theory, states that health workers play a role in the interpersonal environment to promote healthy behaviors and influence people around them ${ }^{[1]}$. Research on health professionals in Nicosia Cyprus General Hospital of 511 participants were 28.2\% smokers and reported smoking in front of patients as much as $13.9 \%$. The history of smokers was more likely to be smokers, and personal smoking behavior habits of health professionals were reluctant to provide education to patients to stop smoking ${ }^{[2]}$.

Smoking behavior is a threat to global health and is the second largest contributor to cardiovascular disease. Exposure to cigarette smoke contributes around $12 \%$ of cardiovascular disease deaths, kills 7 million people each year, and nearly 900,000 nonsmokers die from exposure to cigarette smoke ${ }^{[3]}$. Smoking behavior in the world reaches 1.1 billion people, around $20.2 \%$ of smokers aged $\geq 15$ years old, and 800 million occur in developing countries with low and middle income ${ }^{[4]}$. Indonesia ranks third after China and India, with the most significant number of smoking behaviors in the world $^{[5]}$. In 2025 the WHO projects that the smoking population of Indonesians will increase by $45 \%$ to around 96,776,800 people ${ }^{[6]}$.

Results of Basic Health Research in 2018, the national prevalence of smoking behavior in Indonesia is $29.3 \%{ }^{[5]}$. Based on National Health Indicator Survey Data [Survei Indikator Kesehatan Nasional or SIRKESNA], in 2016, national smoking behavior increased from $24.3 \%$ in 2013 to $28.5 \%$ in 2016 . The prevalence of smoking behavior in men is around $59 \%$, and women are $1.6 \%$. In contrast, prevalence according to residence smoking behavior in rural areas is not much different from living in urban areas with a percentage of $29.1 \%$ and $27.9 \%{ }^{[7]}$.

West Nusa Tenggara [NTB] occupies the fourthhighest position smoking behavior with a percentage of $30.3 \%$ and the age range of starting smoking $\geq 10$ years. This incident indicates that the behavior of the people of West Nusa Tenggara [NTB] are still less aware of the importance of healthy living, including smoking and smoke-free area ${ }^{[5]}$. Indonesia has implemented a No Smoking Area [Kawasan Tanpa Rokok - KTR] policy in the workplace and health facilities, but its implementation in the field is still not consistently implemented ${ }^{[8]}$. Workplaces that implement $100 \%$ smoking-free policies can reduce the prevalence of smoking behavior $6-22 \%$ and reduce $14 \%$ of cigarette consumption every day compared to workplaces that do 
not implement a smoke-free policy ${ }^{[9]}$.

Based on this background, researchers are interested in exploring the "Smoking Behavior on Health Workers" at the Lambu Community Health Center, which is a first-level health facility located in the working area of Lambu District, Bima Regency, West Nusa Tenggara Province.

\section{METHODS}

This study used a qualitative method of phenomenological approach because this research aimed to explore the experience of smoking behavior on health workers in 2019. Participants in this study were six health workers that consisted of five participants work as nurses, and one participant work as a pharmaceutical profession. Data saturation happened in the sixth participant.

Participants were determined based on inclusion criteria. The inclusion criteria were willing to become research participants, health professionals, active smokers, and had taken health education at least Diploma III. The study took place in a puskesmas, named Lambu Public Health Center, Bima Regency, West Nusa Tenggara Province. Data retrieval time was in January 2019, using a snowball sampling technique.

The researchers collected the data using a semistructured interview as a reference for the interview process in exploring the participants' smoking behavior experience. Field notes were to record the interview situation, facial expressions, and participant's body language. A voice recorder used to record the interview process. The researchers did the data collection procedures by conducting research licensing processes following applicable regulations, explaining the rights and obligations of participants, and filling informed consent. There were interviews conducted according to the agreed time and place contract. The in-depth interview process was carried out by asking open-ended interviews about the participant's smoking experience. The duration of the interview process was following previous pilot testing between 30 to 60 minutes.

The process of analyzing data used the Colaizzi method to describe the meaning of experience through identification of essential themes by re-reading all verbatim data from interviews and field notes repeatedly, reviewing the data and making a list of specific questions, articulating the meaning of each particular and significant question by choosing keywords, grouping keywords into categories and themes, validating the findings of the themes to the participants to adjust to the conditions experienced by the participants.

The ethics of this research received an approvement from the Health Research Ethics Committee [Komite Etik Penelitian Kesehatan-KEPK], Faculty of Nursing Unissula Semarang No.521/A.1/FIK-SA/XII/2018

\section{RESULTS}

The age of the participants is between 26-43 years with the education level were diploma and bachelor degree. All participants were male, muslim and majority worked as nurses. The researchers identified seventh themes explaining the smoking habit of Lambu Public Health Center health staff in Bima Regency, West Nusa Tenggara Province. The themes of the study are 1] The early experience of smoking behavior, 2] Reasons to keep smoking, 3] The effects of smoking behavior, 4] Interpersonal and situational influences, 5] The commitment to quit smoking, 6] The problematic smoking behavior to change, and 7] The obstacles to educating people on smoking behavior.

\section{Theme 1: The early experiences of smoking behavior}

Participants revealed the first time they started smoking since middle school, 16 years old, high school, 18 years old, and in college. Some participant expressions are as follows.

\section{"At first, I tried it when I was in middle school around the age of 16" [P5]}

"I started smoking since the third grade of high school around the age of 18." [P3, P6]

"I started smoking since 2013 when I was in college." [P1]

The reasons for starting to smoke are mostly personal factors, the influence of smoking friends or parents, and parents allowing to smoke after graduating high school. Some participants' expressions are in the following.

\section{"Eee... [frowning and brow] I, myself, wanted to smoke. At first, I avoided my friends. I tried smoking when I was alone at the boarding house." [P1]}

"Normally, people here will smoke after they graduate high school. Parents no longer prohibit smoking, as well as in my family." [P4]

The first effects of smoking include feelings of nausea and dizziness, respiratory system disorders such as [itchy throat, coughing, and choking], but after frequent trying, the participants expressed feelings of comfort and ease in enjoying cigarettes. Some participants' expressions are as follows.

\section{"I felt nauseous and dizzy at first. The sensation is different after that. I feel calm." [P1]}

\author{
"At first, I felt dizzy, but over time it feels good, \\ calming, and comforting." [P3]
}


"When I first started smoking, it felt like my throat was itchy and made me cough." [P5]

\section{Theme 2: Reasons to keep smoking}

The reasons for continuing smoking habits among health workers are due to individual psychological factors, the influence of the smoking environment, the influence of smoking friends, and habit. Some participants' expressions are in the following.

"Why did I start smoking .... [silent since thinking]. I just get addicted. I will be nervous if I don't smoke in a day." [P1]

"If now, hmm... [stop to think about something]. I'm addicted to it." [P6]

"Now, there are places to sell cigarettes everywhere. So, it's easy for me to get them." [P4]

"After seeing my friends smoking and drinking coffee, I was tempted to smoke." [P2]

"I have started smoking since my adolescence period. So it is difficult to stop now." [P5]

\section{Theme 3: The effects caused by smoking behavior}

Effects arising from smoking behavior are both negative and positive effects. Negative effects felt by health workers from smoking behavior include health problems such as coughing, aggravating cough symptoms, coughing up phlegm, shortness of breath, and heart pain. Also, economic problems involve spending much money on household spending to buy cigarettes. These officers felt ashamed of their smoking behavior. Some participants' expressions are in the following.

"Normally, I cough, and my wife also complains about my smoking habit. It's just a waste of money. She says

that it's too wasteful, especially since the kids are ready to continue their education." [P4]

"During smoking, I cough a lot. Once did I feel pain in the heart when smoking too much cigarette. But I have reduced the smoking now." [P5]

"I feel ashamed, actually ashamed of myself. People know that I'm a health worker, but I smoke instead." [P2, P3]

The positive effects felt by health workers from smoking habits are feeling calm, relaxed, comfortable, open-minded. They also thought of having a light body and enthusiasm when working. Some participants expressions are as follows.

"My mind calms. Sometimes it feels bland if I don't smoke, especially after eating." [P1]

"Well, when I have a lot going on in my mind, I'll definitely smoke to calm down for a moment." [P6]

Some expressions of enthusiasm work from smoking behavior are as follows.

"Ehh smoking increases enthusiasm when working ..." [P1]

"Once I stopped smoking for about six months, but what I felt was that my body felt heavy and lazy to work." [P4]

\section{Theme 4: Interpersonal and situational influences}

The interpersonal influence on the smoking behavior of health workers involves the influence of the family, the work environment, and the community. The influence of the family is to keep smoking even though they have warned and prohibited. However, in the long run, the family does not care as long as they can earn their own money. Some participants' expressions are in the following.

"Well, actually my wife does not allow me to smoke" [P2]

"My wife often warns me. She told me to smoke outside the house and reduce smoking. " [P3]

"When I'm home, my wife will nag me and tell me to reduce smoking." [P6]

The influence of the work environment is health workers smoking, together with other coworkers and even patients' families. The other coworkers ignore even though some of them have warned not to smoke too often, and the rules are not strict. Some participants' expressions are in the following.

"Well, it's something normal because almost half of the men working here smoke on average, ... and usually those who warn us are female coworkers. They tell us to stay away if we are smoking. " [P2]

"The application of the smoking policy in the workplace is not well monitored. There is no strict supervision for officers or people who smoke in the health center area." [P6] 
The community influences include the habits of health workers often smoking together even though they often have got warnings. As a result, people have often seen their smoking officers perceive mediocrity. Some participants' expressions are in the following.

\section{"Well, the responses vary. Sometimes people wonder why health workers like me smoke. Some find me smoking often as something normal." [P1]}

"Well, people sometimes warn me. Some don't say anything when seeing others smoke." [P2]

Smoking habit at home starts in the morning after breakfast, in the afternoon after work, break time, continues with friends over coffee, and even at night. The smokers smoke at the terrace, the front yard of the house, but rarely inside the house. Some have smoked in the living room and bedroom. The smoking habit of health workers increases in the afternoon until the evening. Some participants' expressions are below.

"I often smoke at home after having a meal and also if friends are visiting while drinking coffee." [P1]

"I usually smoke at home in my free time, or I usually smoke outside. I usually smoke in the front yard of the house rarely in the house." [P2]

"I smoke at home, as usual. I usually smoke in the living room, on the front porch of the house, while drinking coffee." [P5]

The smoking habit in the environment, health workers, smoke when having a break. When there is no patient or the night shifts, they smoke in a parking lot, in a security post, or the corner of the building. Some participants' expressions are as follows.

"When having a break or there are no patients, my friends smoke, and I join them too." [P2].

"I once smoked and joined other friends in the parking lot or open field. It is what we usually do in our free time." [P3]

"I once smoked with one patient's family while I had a night shift in the security post, which happened to be other patient's family there." [P4]

"When I smoke, I will do it in a quiet place that does not bother the patients and their family." [P5]

The situation of smoking in the community is that health workers often smoke during community activities such as during a gathering or celebration and when sitting with neighbors to have a small talk. Some participants' expressions are in the following.
"We both smoke together just to make small talk, and a lot of my friends also smoke." [P1]

"In the community, when we gather, we will also smoke together as in prayer activities, community gatherings because the people here have a smoking habit." [P6]

\section{Theme 5: The commitment to stop smoking}

The participants said they had the urge to quit smoking due to many health negative effects, aggravating pain when sick, quick breathing when working, getting exhausted quickly, or economic factors such as salary problems and feelings of shame as a health worker. They revealed that they once stopped at certain times, such as when having a wet cough, when they were sick, and when trying to join the army. Some participants' expressions are as follows.

"I am now planning to quit smoking again." [P2]

"Hmm, I stop smoking when I am sick ... [looking down]." [P1, P6]

"Yes, I have wanted to stop, but it hasn't worked yet, until now" [P4].

"I am ashamed of myself as a health worker. Well... [inaudible] Ahh, I have already done it. Insya Allah, one day, I will stop smoking. " P5

The state of recovery from illness causes the reason for the recurrence of smoking. The desire to smoke will start again; even smoking habits will be increasing. The environment and friends in the circle may influence smoking addiction. Some participants' expressions explain this matter below.

"Well, at that time, I was sick." [P1]

"Oh yeah, I have been smoking for about six months." [P4]

"I stopped three times, but then I continue smoking again." [P5]

"After recovering, I want to smoke again, and my desire even increases." [P1]

"What makes me smoke again is people in the neighborhood where I live and work mostly smoke." [P4]

"After I recovered, what else can I do? I keep smoking. I feel more comfortable smoking, and my consumption is increasing. " [P6] 


\section{Theme 6: The problematic smoking behavior to change}

All participants said that they had tried to quit, but all failed. One participant stated that it was difficult to stop smoking. Most participants noted that it continued and became a habit that was hard to leave. Some participants' expressions are in the following.

"It's hard to stop smoking even though I've tried. So I can only promise [breathing while looking down] that I will reduce smoking." [P1]

"Well, actually, it is a dilemma, but what else can I

$$
\text { do?." [P5] }
$$

All participants stated that they responded to the family about their smoking habits was by avoiding smoking near them. All participants said they addressed smoking habits at work was by reducing smoking and avoiding smoking near their friends. They also tried to find a far from crowd place so the visitors or patients would not see them. Participants stated the same thing in addressing smoking habits in the community by reducing smoking and trying to avoid smoking in crowded areas. Some participants explain this matter below.

"I usually avoid smoking outside the house." [P3]

"I stay away from children. If the children are around, I will put out the cigarettes first. After they go, I light up another cigarette." [P4]

"To address my smoking habit, I usually reduce smoking at work. If I want to smoke, I will look for a place far from the crowd and smoke with friends as usual." [P6]

\section{Theme 7: The obstacles to educating people on smoking behavior}

The results of this study found that smoking could inhibit health care workers in providing health education for the smoking habit to families. They were anxious to provide health education on smoking habits and to advise patients to stop smoking in public. Health workers revealed the problem of smoking prevention. They did not have expertise in preventing smoking behavior and had never attended specialized smoking prevention training. Some participants' expressions are in the following.

"Hehe ... [smiling] I can't advise other people to stop smoking if I, myself, smoke. So I never do it." [P2]

"I am embarrassed if I have to admit to the public that
I'm smoking. What will people say... [looking down]. It is the same as making a fool of myself in public."

$$
\text { [P3] }
$$

"I have never received special smoking prevention training. " $[P 1, P 2, P 3, P 4, P 5, P 6]$

\section{DISCUSSION}

\section{Theme 1: The early experience of the smoking habit}

According to Pender [2015], the best predictor of behavior is the frequency of similar behavior in the past. Previous experience has direct and indirect effects on the tendency to promote health or vice versa, as obtained in this study. Early experiences of smoking behavior will increase the tendency of smoking behavior of health workers and ignore healthpromoting behaviors ${ }^{[10]}$.

According to Basic Health Research [Riskesdas] in 2007, 2010, and 2013, the age of first smoking was highest in the age group of 15-19 years ${ }^{[8]}$. Research on health workers working in hospitals and primary health services in Saudi Arabia, India, Egypt, and Sudan, found that first-time workers smoked an average age of $18.2 \pm 5.7$ years ${ }^{[11]}$. These results are similar to the results obtained in this study, and in the general hospital in the area of Bali, the highest first-time smoking officer was found in the age group of 16-25 years ${ }^{[12]}$.

The reason for these health workers starting to smoke in this study was due to personal desire, getting tempted to try, environment, smoking friends, and parents smoking factor. Research in Palestine finds the main reason health workers first smoke because they want to try ${ }^{[13]}$. At the smoking cessation clinic in Bahrain, the first time smoking is caused by smoking friends [14] Health workers living with smoking families tend to smoke ${ }^{[2]},{ }^{[11]}$

The impacts felt when first smoking on the health workers are nausea, dizziness, to respiratory system disorders such as itchy throat, coughing, and coughing. When someone smokes for the first time, he will cough and feel dizzy due to a reaction against foreign substances and free radicals ${ }^{[15]}$. Other studies have found the effects of feeling uncomfortable, coughing, and salivating continuously ${ }^{[16]}$. According to Bandura [1985 in Pender 2015], if at the beginning of the habit, smokers only feel the short-term benefits. Then, they will repeat what they have done, as happened to health workers in this study due to the frequency of trying to feel good and enjoy smoking behavior ${ }^{[10]}$.

\section{Theme 2: Reasons to keep smoking}

The reasons for them to continue smoking today are not much different from the first time smoking experience. This study finds that smoking behavior is now more dominantly influenced by individual 
psychological factors such as addiction and anxiety. Psychological factors in the theory of Pender's health promotion model is one of the personal factors that can influence a person's behavior and tendency to conduct certain behaviors such as behavioral tendencies promoting health or vice versa behaviors that do not improve health such as smoking behavior ${ }^{[1]}$.

Individual psychological factors, feelings of addiction, anxiety, and addiction to smoking are closely related to the nicotine content in cigarettes ${ }^{[9]}$. Personal desires influence the smoking behavior of primary health workers in the Arab emirate Union and smoking friends ${ }^{[17]}$. The main reason health workers smoke is due to the influence of smoking friends ${ }^{[18],[19],[20]}$. The smoking environment will tend to smoke compared to associating in a non-smoking environment ${ }^{[21]}$, and the ease of access to smoking in the environment affects smoking behavior ${ }^{[22]}$.

\section{Theme 3: The effects caused by smoking behavior}

The Health Promotion Model explains the effects associated with activities affecting perceived selfconfidence. The more positive feelings towards behavior are, the higher the feelings of efficacy and further positive outcomes increasing self-esteem will be [1]. This study explains the positive effects felt covering the harmful effects of smoking behavior proved. Despite feeling the harmful effects of smoking behavior, health workers continue to the smoking habit because the positive results increase their selfconfidence to keep smoking.

Positive effects felt on health workers in hospitals, and primary health care states that smoking can eliminate stress, feelings of anger, and annoyance ${ }^{[11]}$. The same problem to psychiatric health workers and public hospitals. Smoking creates a feeling of calm and relaxation from stress at work ${ }^{[23]}$. Research at Adel Cairo's Security Forces Hospital has gotten into the habit of smoking to reduce body weight and increase the spirit of activity ${ }^{[24]}$. Research in Mecca finds the reason for smoking by public health workers to reduce stress, relax, and feel energized to stay awake at work ${ }^{[25]}$. related to smoking a major cause of risk factors for chronic obstructive pulmonary disease (COPD) by looking at the symptoms caused by a cough or wet cough and shortness of breath ${ }^{[26],[27]}$. The effects of smoking are associated with an increased risk of cardiovascular disease ${ }^{[28]}$. The study also reveals the economic problems of families as a result of smoking. Low financial status has the highest percentage of smoking behavior. People on low incomes tend to smoke and force themselves to buy cigarettes, even though the salary is small. Health workers express their feelings of shame as health professionals due to smoking behavior. Smokers harm their profession among feelings of guilt as health workers ${ }^{[25]}$.
The perceived negative effect on smoking behavior among health workers only slightly increases selfconfidence to stop smoking. However, the more significant positive effect is to increase the confidence of smoking behavior in health workers. The Health Promotion Model by Pender states that when positive affect or emotion is associated with a behavior, the likelihood of commitment and action increases ${ }^{[1]}$.

\section{Theme 4: Interpersonal and situational influence}

The Pender's Health Promotion Model states that families, groups including coworkers, community groups, and health service providers are essential resources that can increase or reduce commitment to the realization of behaviors that promote health ${ }^{[1]}$. The interpersonal influence [family, coworkers, and the community] on smoking behavior in health workers increases commitment to smoking behavior and ignores behavior that promotes health.

Al Turkstani et al. [2015] report that health workers who smoke often get complaints and warnings from families ${ }^{[25]}$. Prohibition of smoking at home will increase awareness to stop smoking ${ }^{[29]}$. Although the family warns and prohibits smoking, in the long run, they will ignore the smoking habit as long as the smokers can earn their own money. The influence of the work environment dramatically determines a person's smoking habits. The habits of health workers smoking and monitoring the rules are not strict. Research in Manado hospitals found that a non-strict smoking ban policy at work affected smoking habits in the work environment because there were no sanctions to provide a deterrent effect for the rule-breakers ${ }^{[30]}$. Smoking culture in the community will tend to influence the smoking behavior of individuals ${ }^{[31]}$. The same problem in Nepal, the smoking behavior of health workers, is influenced by the social environment that is around them ${ }^{[32]}$.

The Health Promotion Model states that situational influences can increase or decrease commitment to behavior promoting health ${ }^{[1]}$. This study reveals the situation of health workers smoking behavior at home that is when the morning before leaving for work, after eating, when resting, smoking with friends while drinking coffee, and the time until the evening. Smoking habits in health workers do not look at a specific time. Health workers reveal smoking if there is an opportunity ${ }^{[28]}$.

This study reveals the situation of health workers smoking behavior in the workplace. They smoke when the patients are sleeping, during the night shift, and smoking in the parking lot, security post, and the corner of the building. The smoking behavior of health workers in the workplace, most of them reported smoking in the hospital, smoking in the hospital staff, in the staff room, and the hospital canteen. The health workers revealed that the patients could not see 
smoking habits ${ }^{[33]}$. Smoking habits of health workers in the workplace in this study are to avoid boredom in their free time.

This study also reveals the situation of smoking behavior of health workers in the community when there are social activities or when sitting together to have a small talk. Smoking behavior can increase acceptance in the community. The smoking situation of health workers in this study deals a lot with the community on particular events ${ }^{[34]}$.

\section{Theme 5: The commitment to stop smoking}

Commitment to an action plan has a smaller tendency to manifest into expected behavior when competing demands arise that the person has little control over them, and these demands need immediate attention ${ }^{[1]}$. This study reveals that all health workers have the desire to quit smoking and even tried to quit smoking, but they are unable to compete with the demands for smoking relapse so that the commitment to stop smoking cannot be maintained.

This study reveals that all health workers have the desire to stop smoking. Taiwanese hospitals showed the same thing; about $93 \%$ of 848 health workers had an interest in quitting smoking ${ }^{[35]}$. In Saudi Arabia, $80 \%$ of 200 health workers had the desire to stop smoking [36]. In Greece, hospitals there revealed the experience of health workers had stopped smoking but had not been successful ${ }^{[37]}$.

The reason for health workers to stop smoking in this study reveals health factors, economic factors, cigarette tastes, and feelings of shame. The majority of health workers in Mecca report thinking about quitting smoking as it is harmful to health ${ }^{[25]}$. Other studies reveal the reason for health workers to stop smoking due to the high expense of buying cigarettes [24] [33]. When someone finds his favorite cigarette tastes, he will keep buying the same type. However, if it does not suit his liking, he will consider other cigarettes ${ }^{[38]}$. The reason to stop smoking is because of feelings of shame as health workers ${ }^{[25]}$.

This study reveals that the reasons for the recurring smoking habit by health workers' smoking habits are due to the influence of friends, environmental impacts, feeling uneasy, and after recovery. Research on health workers in Saudi Arabia reports that smoking relapses are caused by living with other smokers, having friends who also smoke, feeling uneasy or stressed, and smoking nicotine addiction ${ }^{[25]}$. Research states that smoking cues in the environment, the presence of smokers in the environment, nicotine addiction, and misconceptions about the dangers of smoking challenge people to stop smoking ${ }^{[39]}$.

Environmental support is very influential in the success of the commitment to stop smoking. As seen in this study, one of the reasons for the recurrence of smoking comes from the environmental factor ${ }^{[35]}$. state that environmental factors will support the success of quitting smoking. Supported research on ex-smokers who reveal the desire to smoke arises when in a smoker and social environment is crucial to the success of smoking cessation commitments ${ }^{[40]}$.

\section{Theme 6: The complicated smoking habits}

The Health Promotion Model states that commitment to an action plan has a smaller tendency to manifest into expected behavior. If other actions are active, they will be preferable over targeted practice ${ }^{[1]}$. This study reveals that smoking behavior among health workers has difficulty maintaining a commitment to stop smoking. Smoking behavior among health workers that have smoking habits is difficult to change even though they have tried. They tend to fail and can only reduce or stay away from the non-smokers.

Quitting smoking is not easy because smoking is a difficult habit. To successfully stop smoking requires a process and exercise. Smokers can go through perceived obstacles such as the habit of wanting to return to smoking, and the perception of the effects of tobacco provides calm. Smoking has become a part of people's culture and norms in daily life ${ }^{[31]}$. Smoking habit requires repeated interventions and effective treatments. It is necessary to take into account the individual's reasons for smoking, their environment, the resources available, and the perception of the individual stopping smoking to support the success of an intervention ${ }^{[41]}$. In addressing smoking habits, health workers tend to reduce smoking in the workplace and the community. They will also avoid smoking near family or coworkers, and try to smoke in quiet places. Health workers in Saudi Arabia have a habit of concealing smoking behavior from coworkers as well as to others. It is in response to their smoking habits ${ }^{[25]}$.

\section{Theme 7: The obstacles to educating people on smoking behavior}

Behavior that promotes health is the endpoint of achieving a positive manifestation of health. The Health Promotion Model states that health workers play a role in the interpersonal environment that influences [role models] health in other people throughout their lives, but instead, they find health workers having health education challenges caused by their smoking habit ${ }^{[10]}$.

The problems faced by health workers who smoke are not providing health education for smoking behavior to families. They are unable to give health education for smoking habits in public and to advise patients to stop smoking. In the Arab Emirate Union, the health workers have a responsibility in health education for the smoking habit. However, health workers who smoke, provide less education, and encourage patients to stop smoking [17]. A similar problem happens to the health workers in Jordan. 
People who smoke give less advice to stop smoking in patients ${ }^{[28]}$. Other research states that health workers who smoke have a lower likelihood of advising smoking cessation than health workers who do not smoke. Smoking status hurts efforts to prevent smoking [42], [19].

Another health problem for health workers is that they do not have expertise in health education for smoking behavior. They have never conducted specialized training in preventing smoking behavior. The health workers in Vietnam barely have specialized training and smoking prevention education programs established by the health department ${ }^{[43]}$. Similar results find that the most commonly reported challenges to smoking prevention lack of specialized smoking prevention training ${ }^{[44]}$.

\section{CONCLUSION}

Based on the results and discussion in this study, the researchers conclude that smoking behavior in Puskesmas Lambu health staff, Bima, West Nusa Tenggara produces eight themes. They are: 1] The early experience of smoking behavior, 2] Reasons to keep smoking, 3] The effect caused smoking behavior, 4] Interpersonal and situational influence, 5] The commitment to stop smoking, 6] The complicated smoking habits, 7] The obstacles to educating people on smoking behavior..

Evaluating the smoking ban policy at the Center for Public Health Services [PUSKESMAS] is to apply the most strict rules. Conducting specialized training in the prevention of smoking behavior in health workers to gain particular expertise and having responsibility for smoking prevention is necessary. It is also essential for health institutions to include lessons on preventing smoking behavior in the curriculum so that graduates of health workers have expertise in the field of smoking prevention.

\section{ACKNOWLEDGMENT}

We thank all of the participating health workers of Lambu public health center for sharing their experiences and opinions. We also thank the head of Lambu public health center for the support and for facilitate this research.

\section{REFERENCES}

[1] Alligod, M. R. Pakar Teori Keperawatandan Karya Mereka. Edisi Indonesia ke 8. Vol. volume 2 [A. Y. S. Hamid \& K. Ibrahim, eds.]. Elsevier.; 2017.

[2] Zinonos S, Zachariadou T, Zannetos S, Panayiotou AG, Georgiou A. Smoking prevalence and associated risk factors among healthcare professionals in Nicosia general hospital, Cyprus: a cross-sectional study. Tob Induc Dis. 2016 Dec;14[1]:14.

[3] World Health Organization. WHO global health days: World No Tobacco Day Tobacco and heart disease. [Internet]. 2018. Available from: http://www.who.int/campaigns/no-tobaccoday/2018/event/en/

[4] WHO. World No Tobacco Day: Tobacco and Heart Disease. [Internet]. 2018. Available from: Retrieved from http://www.who.int/news-room/detail/31-052018-world-no-tobacco-day-tobacco-and-heartdisease

[5] Health Ministry of Indonesia. Situasi Umum Konsumsi Tembakau di Indonesia [Current Tobacco Consumption in Indonesia]. [Internet]. InfoDATIN.; 2018. Available from: http://www.depkes.go.id/resources/download/pusdat in/infodatin/infodatin tembakau per halaman.pdf

[6] World Health Organization. WHO global report on trends in prevalence of tobacco smoking, 2015. [Internet]. 2015 [cited 2020 Jan 4]. Available from: http://apps.who.int/iris/bitstream/10665/156262/1/97 89241564922_eng.pdf

[7] Kemenkes RI. Profil Kesehatan Indonesia tahun 2016. Available from: www.kemkes.go.id/

[8] Kemenkes RI. Infodatin: Hari Tanpa Tembakau Sedunia. [Internet]. 2013. Available from: https://doi.org/24422-7659

[9] Rockville, MD. How Tobacco Smoke Causes Disease: The Biology and Behavioral Basis for Smoking-Attributable Disease: A Report of the Surgeon General: [590462011-001] [Internet]. American Psychological Association; 2010 [cited 2020 Jan 4]. Available from: http://doi.apa.org/getpe-doi.cfm?doi=10.1037/e590462011-001

[10] Pender NJ, Murdaugh CL, Parsons, MA. Health promotion in nursing practice. Seventh edition.Boston: Pearson; 2015. 342 p.

[11] Mahfouz AA, Shatoor AS, Al-Ghamdi BR, Hassanein MA, Nahar S, Farheen A, et al. Tobacco Use among Health Care Workers in Southwestern Saudi Arabia. BioMed Res Int. 2013;2013:1-5.

[12] Aryda LNT, Sundari LPR. Profilperokokpadatenagakesehatan di rumahsakitjiwaProvinsi Bali 2015.

[13]Zabadi HA, Musmar S, Hassouna A, Shtaiwi D. Cigarettes and Water Pipe Smoking Prevalence, Knowledge, and Attitudes Among the Palestinian Physicians in the West Bank. Tob Use Insights. 2018 Jan;11:1179173X1881336.

[14] Hamadeh RR, Ahmed J, Al Kawari M, Bucheeri S. Smoking behavior of males attending the quit tobacco clinics in Bahrain and their knowledge on tobacco smoking health hazards. BMC Public Health. 2018 Dec;18[1]:199.

[15]Fathin - 2015 - Analisis Faktor-Faktor Penyebab Perilaku Merokok Remaja.pdf.

[16] Salasa MR, Rochana T, Alimi MY. Fenomenasiswaperokok [studikasus di SMA Negeri 3 Demak]. J Educ. 2013;13.

[17] Al Hosani S, Al Ali M, Al-Marashda K, Al-Shamsi N, Al-Ansari T, Al-Behandy A, et al. Smoking prevalence, attitudes and behaviors of primary healthcare providers and its impact on their smoking cessation counseling practices. Ibnosina $\mathrm{J}$ Med Biomed Sci. 2015;7[2]:47. 
[18] Hapsari - 2013 - Perbedaan Perilaku Merokok pada Perawat dan Non- Perawat di RSUD Dr. MOEWARDI.pdf.

[19] Duaso MJ, Bakhshi S, Mujika A, Purssell E, While AE. Nurses' smoking habits and their professional smoking cessation practices. A systematic review and meta-analysis. Int J Nurs Stud. 2017 Feb;67:3-11.

[20] Chandrakumar S, Adams J. Attitudes to smoking and smoking cessation among nurses. Nurs Stand. 2015 Oct 28;30[9]:36-40.

[21] Windahsari N, Candrawati E. Hubungan faktor lingkungan dengan perilaku merokokpadaremajalaki-laki di desa kabupaten mojokerto. Nurs News [Meriden]. 2017; 2:15.

[22] Khoirunnisa A. Beberapa faktor yang mempengaruhi praktik merokok santri di pondok pesantren darut taqwa kota semarang. J Kesehat Masy. 2019;7:12.

[23] An F-R, Xiang Y-T, Yu L, Ding Y-M, Ungvari GS, Chan SW, et al. Prevalence of Nurses' Smoking Habits in Psychiatric and General Hospitals in China. Arch Psychiatr Nurs. 2014 Apr;28[2]:119-22.

[24] Khattab AM, Abdel Fattah EB, Abozahra AKEA. Study of smoking habit among soldiers in Cairo Security Forces Hospital. Egypt J Chest Dis Tuberc. 2017 Apr;66[2]:267-77.

[25] AlTurkstani A, Alkail B, Hegazy A, Asiri S. Knowledge, attitude, and practice among primary health-care physicians toward smoking cessation in Makkah, Saudi Arabia. Int J Med Sci Public Health. 2016;5[4]:714.

[26] Nobile CGA, Bianco A, Biafore AD, Manuti B, Pileggi C, Pavia M. Are primary care physicians prepared to assist patients for smoking cessation? Results of a national Italian cross-sectional web survey. Prev Med. 2014 Sep;66:107-12.

[27] Dar-Odeh N, Alnazzawi A, Shoqair N, Al-Shayyab MH, Abu-Hammad O. Waterpipe Tobacco Smoking among Dental Practitioners: Prevalence and Health Perceptions. Tob Use Insights. 2016 Jan;9: TUI.S40568.

[28] Alkhatatbeh M, Alefan Q, Alzghool M. Smoking prevalence, knowledge, and attitudes among primary healthcare professionals: a study from Jordan. East Mediterr Health J. 2016 Dec 1;22[12]:872-9.

[29] Ramadhan K. Hubunganlaranganmerokok di rumah dengan keberhasilan berhenti merokok. J Profesi Med J Kedokt Dan Kesehat [Internet]. 2017 Oct 6 [cited 2020 Jan 4];11[1]. Available from: https://ejournal.upnvj.ac.id/index.php/JPM/article/vi ew/209

[30] Muliku HR, Polii B, Kumurur V. Analisispengembangankawasantanparokok di rumah sakit tingkat III Robert WolterMongisidi Manado. 2017.

[31] Sheals K, Tombor I, McNeill A, Shahab L. A mixedmethod systematic review and meta-analysis of mental health professionals' attitudes toward smoking and smoking cessation among people with mental illnesses: Mental health professionals' views on smoking. Addiction. 2016 Sep;111[9]:1536-53.
[32] Ghimire M, Sharma A, Ghimire M. Smoking and Depression among Healthcare Workers. J Lumbini Med Coll. 2014 Jun 30;2[1]:21.

[33] Mizher IY, Fawaqa SI, Sweileh WM. Prevalence and personal attitudes towards tobacco smoking among Palestinian healthcare professionals: a cross-sectional study. Addict Sci Clin Pract. 2018 Dec;13[1]:17.

[34] Tombor I, Shahab L, Herbec A, Neale J, Michie S, West R. Smoker identity and its potential role in young adults' smoking behavior: A metaethnography. Health Psychol. 2015 Oct;34[10]:9921003.

[35] Chang Y-Y, Yu S-M, Lai Y-J, Wu P-L, Huang K-C, Huang H-L. Improving smoking cessation outcomes in secondary care: Predictors of hospital staff willingness to provide smoking cessation referral. Prev Med Rep. 2016 Jun;3:229-33.

[36] Mansour, Youssef, Nemenqani - 2013 Contextualizing Smoking among Saudi Nurses Risk Factors, Effects, and Desire for Quitting.pdf.

[37] Vagropoulos I, Tsilchorozidou T, Tsinopoulos G, Salonikidou Z, Mouratova M, Giavropoulou M, et al. Smoking habits among the hospital staff of a General Hospital in Northern Greece: a long way for smokefree hospitals. Monaldi Arch Chest Dis [Internet] 2016 Feb 11 [cited 2020 Jan 4];65[3]. Available from: http://www.monaldiarchives.org/index.php/macd/article/view/562

[38] Andini AF. Dampak stress terhadap keputusan seseorang untuk merokok. Open Science Framework; 2019 Mar [cited 2020 Jan 4]. Available from: https://osf.io/nc5py

[39] Rezk-Hanna M, Sarna L, Petersen AB, Wells M, Nohavova I, Bialous S. Attitudes, barriers and facilitators to smoking cessation among Central and Eastern European nurses: A focus group study. Eur J Oncol Nurs. 2018 Aug;35:39-46.

[40] Suri SI. Studifenomenologi : pengalaman psikologis mantan perokok dalam menghentikan kebiasaan merokok di Kota Bukittinggi. 2018;9.

[41] Salahuddin N. Smoking cessation strategies for busy clinicians. Pakistan Journal of Chest Medicine. Retrieved from Am Boards Intern Med Pulm Med Crit Care Med. 2015; Available from http://pjcm.net/index.php/pjcm/article/view/195

[42] Duaso MJ, McDermott MS, Mujika A, Purssell E, While A. Do doctors' smoking habits influence their smoking cessation practices? A systematic review and meta-analysis: Doctors' smoking and their smoking cessation practice. Addiction. 2014 Nov;109[11]:1811-23.

[43] Shelley D, Nguyen L, Pham H, VanDevanter N, Nguyen N. Barriers and facilitators to expanding the role of community health workers to include smoking cessation services in Vietnam: a qualitative analysis. BMC Health Serv Res. 2014 Dec;14[1]:606.

[44] Nguyen N, Nguyen T, Chapman J, Nguyen L, Kumar $\mathrm{P}$, VanDevanter $\mathrm{N}$, et al. Tobacco cessation in Vietnam: Exploring the role of village health workers. Glob Public Health. 2018 Sep 2;13[9]:1265-75. 